\title{
Investigation of the contribution of soil conditions to damage and failure of RC structures in Adapazarı
}

\author{
${ }^{1 *}$ Naci CAGLAR, ${ }^{2}$ Zehra Sule GARIP and ${ }^{1}$ Nihan TURAN ALA \\ ${ }^{1}$ Department of Civil Engineering, Engineering Faculty, Sakarya University, 54187 Sakarya, Turkey \\ ${ }^{2}$ Department of Civil Engineering, Engineering Faculty, Karabuk University, 78100 Karabuk, Turkey
}

Geliş Tarihi: 2016-03-22 Kabul Tarihi: 2016-06-27

\begin{abstract}
During the $17^{\text {th }}$ August 1999 Marmara earthquake, the soil has played important role as a contributing factor in the failure of Reinforced Concrete (RC) moment resisting frame buildings built in Adapazari. In this study, the differences of contributing effects on the filure of RC buildings which were built in the soft soil such as Adapazari downtown and stiff soil such as Maltepe has been investigated. Various two dimensional soilstructure models are formed with the simulations of buildings, which had some irregularities suh as soft story, weak stoey and short column effect, and soil properties of Adapazari downtown and Maltepe. The dynamic analysis of the soil-structure models subjected to Marmara earthquake was carried out using SAP2000 software packet program. The outcomes of lateral top displacement of SSI models with respect to soil conditions were presented as graphs and the results were discussed.
\end{abstract}

Keywords: Damage, Building failure, Soft storey, Weak storey, Short column effect, Soft soil, Finite element analysis

\section{Introduction}

Turkey is located in one of the most active earthquake zone which has earthquake periods quite often with shortest return periods. The earthquakes caused loss of lives in the history. During the last century, more than twelve major earthquakes with minimum magnitudes $7(\mathrm{Mw})$ caused significant casualties, severe damage to a lot of structures and lifelines in Turkey. In the last century, approximately 500.000 building collapsed and were heavily damaged. Marmara Earthquake occurred with the magnitude of 7.4 on 17 August 1999 (Fig. 1). This earthquake caused severe damage to hundreds of structures and lifelines in the City of Adapazari. In the earthquake a total of 5078 buildings ( $27 \%$ of the building stock) were severely damaged or destroyed in Adapazari [1-2]. The construction quality of $\mathrm{RC}$ structures in the Adapazarı varied widely. Many of the failures and collapses of RC moment resisting frame buildings are attributed to the formation of soft first storeys, weak stories and short column effect. During the 17th August 1999 Marmara earthquake the soil has also played important role as a contributing factor in the failure of RC moment resisting frame buildings built in Adapazari. Most of buildings were affected and the majority of buildings sank. Local variations of Adapazari soil have played an important role in the ground failure and associated building damage [2-3]. This results have revealed that taking into account the effect of soil properties provides an important contribution to understand the seismic response of buildings. In recent years, most of researchers have been performed a lot of studies regarding the effects of soil structure interactions (SSI) on the dynamic seismic response of buildings [4-6]. Investigating the soil structure interactions of $\mathrm{RC}$ buildings that are built on soft soils is potentially of great importance. In this study, dynamic analyses of 45 soil-structure models were carried out. The aim of the present study is to monitor the contribution of soil effect on the failure of $\mathrm{RC}$ moment resisting frame buildings in Adapazari with soft storey, weak stories and short column effect. The effect of ground water was also included to the study.

\section{Methodology of SSI Analysis}

Seismic soil-structure interaction (SSI) analysis is a major topic in earthquake engineering because of the dynamic response of structures, especially for stiff and massive structures founded on the relatively soft ground, is strongly influenced by the interaction between soil and the structure. In recent years, numerous researchers have been performing a lot of studies regarding the effects of SSI on the dynamic seismic response of buildings. Despite the dynamic SSI effects could be neglected for regular flexible buildings on rock or very stiff soil, they should be significantly taken into account for structures founded on relatively flexible soil[7]. 


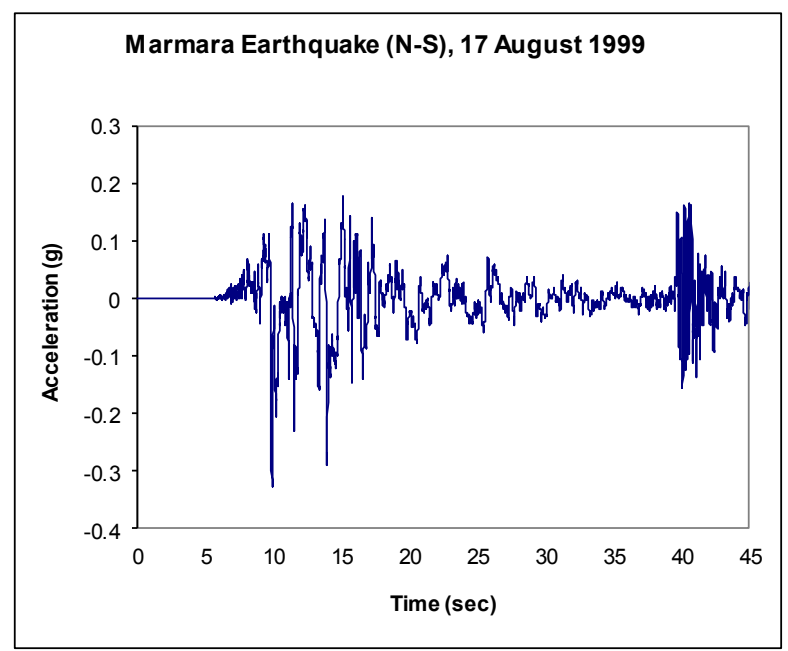

Fig. 1. Marmara earthquake records from Yarımca-Petkim station.

There are two main methods dealing with soilstructure interaction, namely the direct method and the substructure method. In this study, the direct method was used to carry out dynamic analysis of soil-structure models. In the direct method, the response of the soil and structure is determined simultaneously by analysing the idealised soilstructure system in a single step [8]. The soil with the superstructure is modelled until the artificial boundary (Fig. 2). In some conditions where it is impossible to cover the unbounded soil domain with finite elements with bounded dimensions the Substructure Method is used as an alternative. Lysmer and Kuhlemyer [9] proposed a special frequency independent viscous dashpot boundary on the interface nodes in all directions.

In the SSI analyses, the appropriate boundary conditions need to be applied to avoid the reflection of emanating waves from the artificial boundaries back into the interior domain. In the Finite Element models, the large-scale mesh is required to take account of the surrounding soil medium which is bounded by the far-field that is represented by artificial boundaries. In numerical modelling of wave propagation, the special boundary conditions, which might be referred to as radiation damping, are used to compensate the problems arising as artificial boundaries to introduce artificial reflections that contaminate the solution. These special boundary conditions such as transmitting, non-reflecting and silent boundaries absorb the wave energy. The non-reflecting viscous boundaries have been widely used for various dynamic SSI problems [9-11]. These boundaries must be identified far away from the structure or source of dynamic load as they are only capable to transmit plane and cylindrical waves.

\section{Numerical Application}

In this study, two dimensional soil-structure models were set to investigate the effects of soil on failure of RC moment resisting frame buildings in Adapazari (Fig. 3). The study was limited with just Adapazari downtown and Maltepe soil conditions and the soil profiles were obtained from the study of Sacio at all [2].

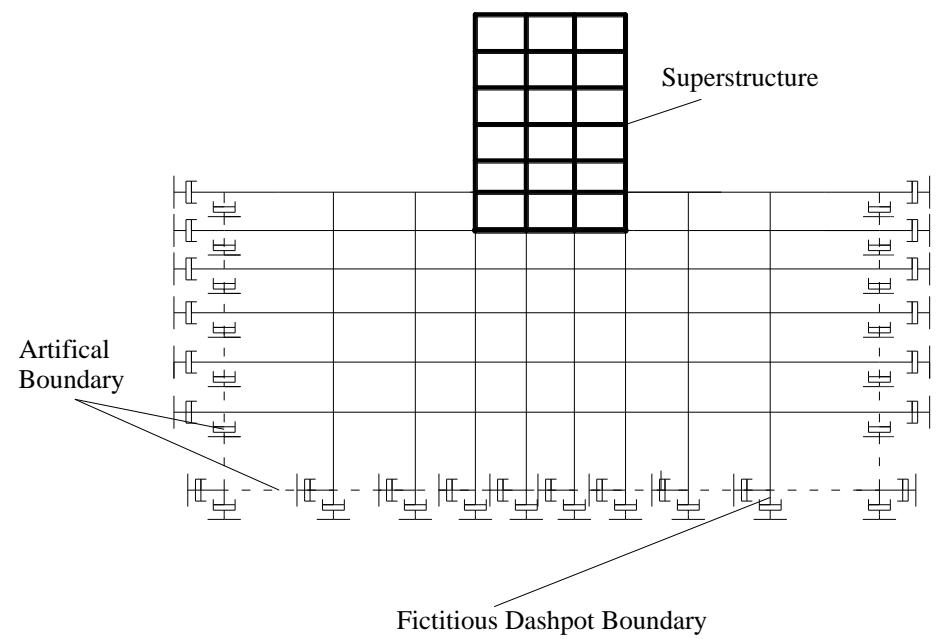

Figure 2. Direct method configuration 
They investigated the subsurface conditions of Adapazari downtown and developed the four general subsurface site categories (Table 1, Fig. 4). The Maltepe, where it is located in south part of Sakarya and it is just $6 \mathrm{~km}$ away from the Adapazari downtown, soil condition was also included to study to compare the response of $\mathrm{RC}$ buildings which were built in stiff and soft soils.

Time history analyses of 45 different soil-structure models were carried out by using SAP2000. These soil-structure models were installed with 5 different substructure models (Fig. 4) and 9 different superstructure models (Table 2). The substructures were modelled in constant soil depths of SLD $=15 \mathrm{~m}$ and constant width of SLL $=315 \mathrm{~m}$. The Lysmer boundaries consisting of dash pots specified to effectively reduce reflection of waves and eliminate artificial resonance frequencies are used in the modelling the artificial boundaries of the soil. Ground water table (GWT) is varying depth due to the seasonal change in Adapazari. Therefore GWT also included to obtain more relevant results. Due to the GWT, the shear modulus was reduced to $1 / 10$ of the original stiffness to model the soil layers [12].

Table 1. Soil general properties

\begin{tabular}{|c|c|c|c|c|}
\hline Soil Layers & $\begin{array}{c}\text { Modulus of } \\
\text { elasticity } \\
\text { E, (MPa) }\end{array}$ & $\begin{array}{c}\text { Unit weight } \\
\rho\left(\mathbf{k N} / \mathbf{m}^{3}\right)\end{array}$ & $\begin{array}{c}\text { Poisson's ratio } \\
v\end{array}$ & $\begin{array}{c}\text { Shear wave } \\
\text { velocities } \\
(\mathbf{m} / \mathbf{s e c})\end{array}$ \\
\hline Fill & 15 & 17.16 & 0,45 & 100 \\
\hline $\mathrm{CH}$ & 50 & 20.30 & 0,40 & 100 \\
\hline Dense Sand & 120 & 19.62 & 0,33 & 150 \\
\hline ML & 13 & 17.16 & 0.45 & 60 \\
\hline SM/ML & 70 & 17.16 & 0.33 & 150 \\
\hline CL or CL/ML & 15 & 17.16 & 0.45 & 60 \\
\hline $\begin{array}{l}\text { CH/CL with } \\
\text { ML/SM layers }\end{array}$ & 56 & 19.62 & 0.40 & 100 \\
\hline Clay Stone & 1200 & 19.62 & 0.45 & 500 \\
\hline
\end{tabular}

Soil Type 1

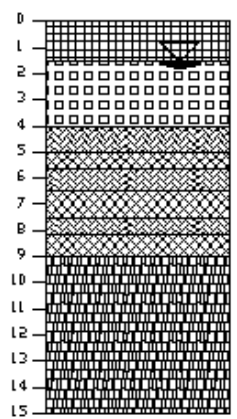

Soil Type 2

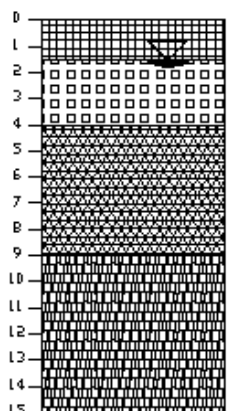

$\mathrm{T}=2,1778 \mathrm{sec}$
Soil Type 3

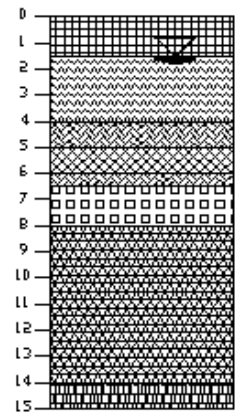

Soil Type 4

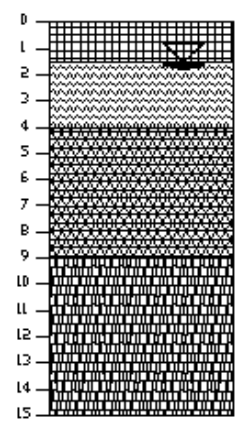

Maltepe

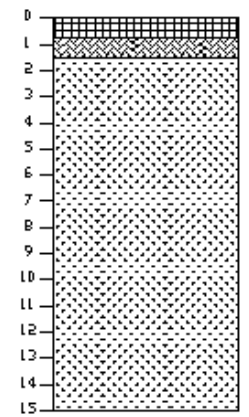

$\mathrm{T}=1,8400 \mathrm{sec}$

$\mathrm{T}=0,1449 \mathrm{sec}$

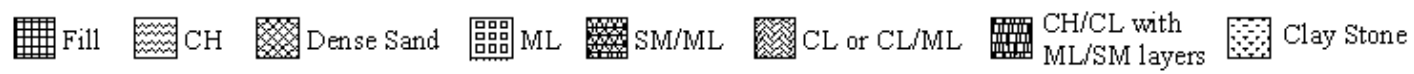

Figure 4. Generalized soil profiles and fundamental periods of Adapazari [2] and Maltepe

Table 2. Model types were selected to simulate the weak storey, soft storey and short column effect problems

\begin{tabular}{|c|c|c|c|c|c|}
\hline \multicolumn{2}{|c|}{ Model Types } & Structure & $\mathrm{h}_{\mathrm{G}}$ & stories $\mathrm{x} \mathrm{h}_{\mathrm{N}}$ & $\mathrm{T}(\mathrm{sec})$ \\
\hline \multirow{3}{*}{ Model A } & \multirow{3}{*}{$\begin{array}{l}\text { Weak } \\
\text { Story }\end{array}$} & Type 1 & $4 \mathrm{~m}$ & $3 \times 3 m$ & 0,2798 \\
\hline & & Type 2 & $5 \mathrm{~m}$ & $3 \times 3 m$ & 0,3650 \\
\hline & & Type 3 & $4 m$ & $5 \times 3 m$ & 0,4772 \\
\hline \multirow{3}{*}{ Model B } & \multirow{3}{*}{$\begin{array}{c}\text { Soft } \\
\text { Storey }\end{array}$} & Type 1 & $3 \mathrm{~m}$ & $3 \times 3 m$ & 0,1367 \\
\hline & & Type 2 & $5 \mathrm{~m}$ & $3 \times 3 m$ & 0,2673 \\
\hline & & Type 3 & $3 \mathrm{~m}$ & $5 \times 3 \mathrm{~m}$ & 0,1802 \\
\hline \multirow{3}{*}{ Model C } & \multirow{3}{*}{$\begin{array}{c}\text { Short } \\
\text { Column }\end{array}$} & Type 1 & $3 m$ & $3 \times 3 m$ & 0,0763 \\
\hline & & Type 2 & $5 \mathrm{~m}$ & $3 \times 3 m$ & 0,0842 \\
\hline & & Type 3 & $3 \mathrm{~m}$ & $5 \times 3 m$ & 0,1135 \\
\hline
\end{tabular}




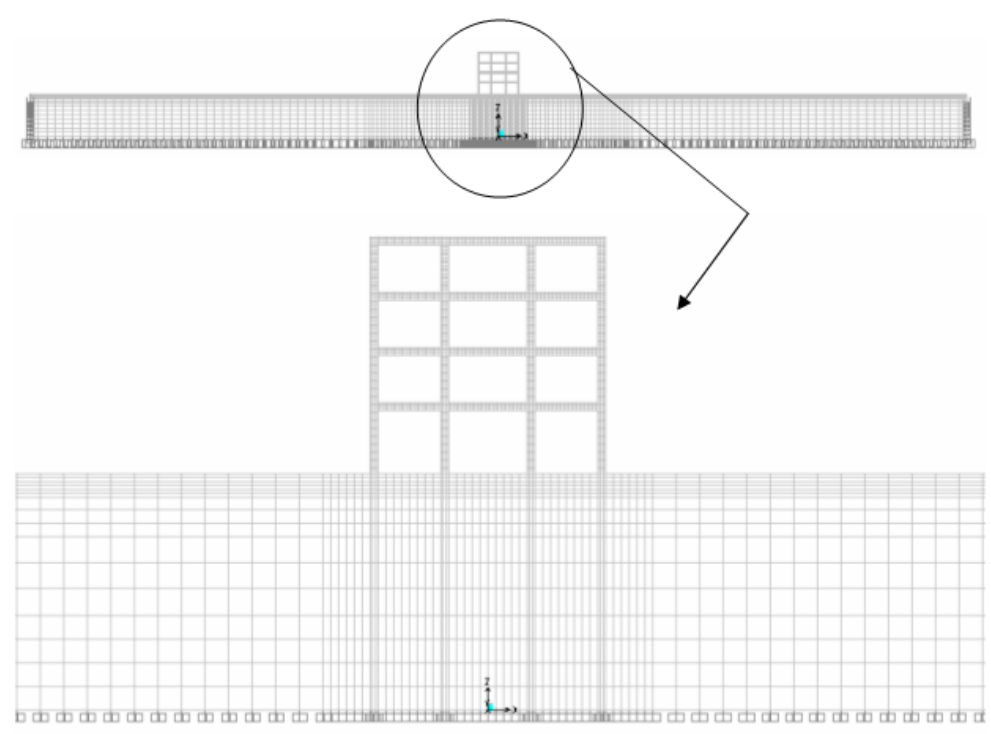

Figure 3. The general FEA mesh of soil-structure models

In the modelling of superstructures, the serious of problems that caused structures failure during the earthquake such as weak stories, soft storey and short column effect were considered and 3 different model types were selected. Model A type was constituted to simulate the response of $\mathrm{RC}$ building built with weak storey problem. Many buildings were damaged due to weak storey in Adapazari during the earthquake (Fig. 5). The weak story is higher than upstairs stories. In the building had weak storey, the height of upstairs is relatively shorter respect to the first storey. The height of first storey in a lot of residential and commercial buildings is lofty in Adapazari. These differences are usually created by sharp changes in stiffness, mass and strength. This problem was caused to diminish in the lateral stiffness and strength of firststorey columns. During the earthquake, the presence of a weak storey results with increased deformation demands significantly. Many failures and collapses can be attributed to this problem, coupled with lack of deformability of poorly designed columns [13].

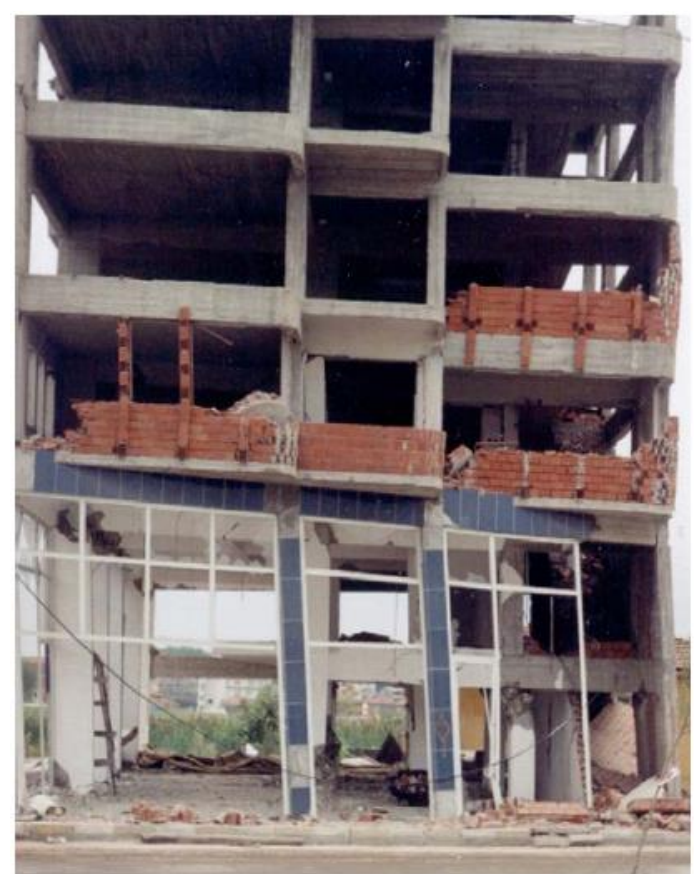

Figure 5. Failure on ground story due to week story [1] 
Model B type was formed to simulate the response of RC building which had soft storey problem. This problem is one of the main contributing factor to the collapse of many multi-storey $\mathrm{RC}$ buildings during the earthquakes. Because the first stories have been often used as stores and commercial areas, most of the buildings in Adapazari had soft stories at the ground story (Fig. 6). In the first story level were generally enclosed with glass windows instead of brick infill walls and heavy masonry infill walls start immediately at the above stories. The lateral stiffness and strength suddenly changes. During the earthquake, the deformation demands significantly increases because of the presence of the soft stories and the burden of energy dissipation on the first-storey columns comes out [13]. The increasing of the deformation coupled with lack of deformability of poorly designed columns can be exposed to many of the failures and collapses of RC moment resisting frame buildings in Adapazari.

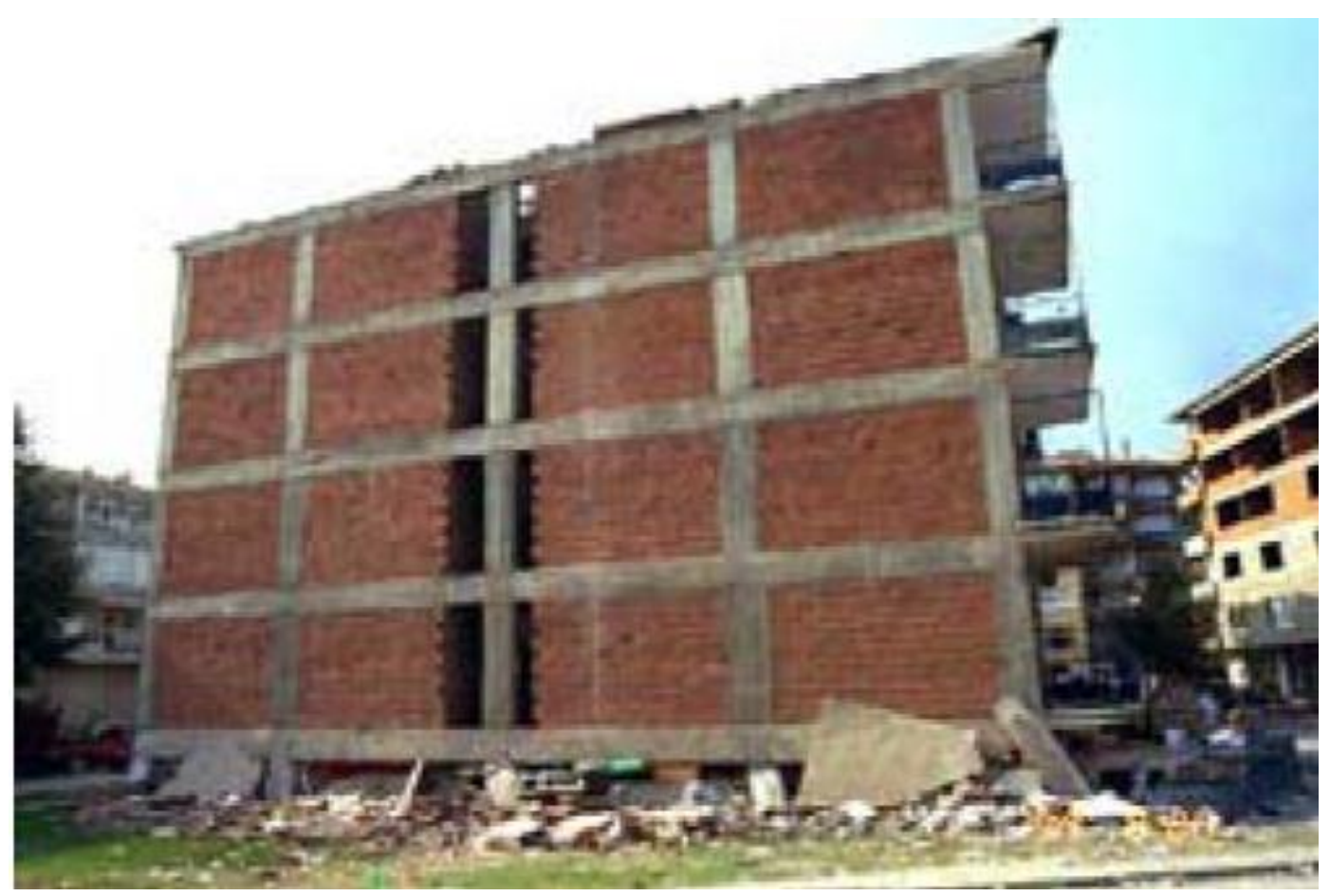

Figure 6. Failure on ground story due to soft story [14].

Model C type was constituted to simulate the response of $\mathrm{RC}$ building which had short column problem. The sort column effect is one of the main reason caused to collapse of the building because of the damage many columns during the earthquake (Fig. 7). When the column length is relatively small, its stiffness increases and becomes stiffer and more rigid in bending. If the stiffness of column was increased, the column is able to take more bending moment and shear forces causing a shear failure. The infill walls also significantly contributed to the lateral stiffness of buildings. If the infill walls in the RC moment resisting frame were made shorter than the column length, the columns are unable to flex under the lateral loads from the earthquake due to the in-plane stiffness of the infill walls. This problem can be caused to damage the columns because of occurring of the excessive shear forces in the column length during the earthquake. 


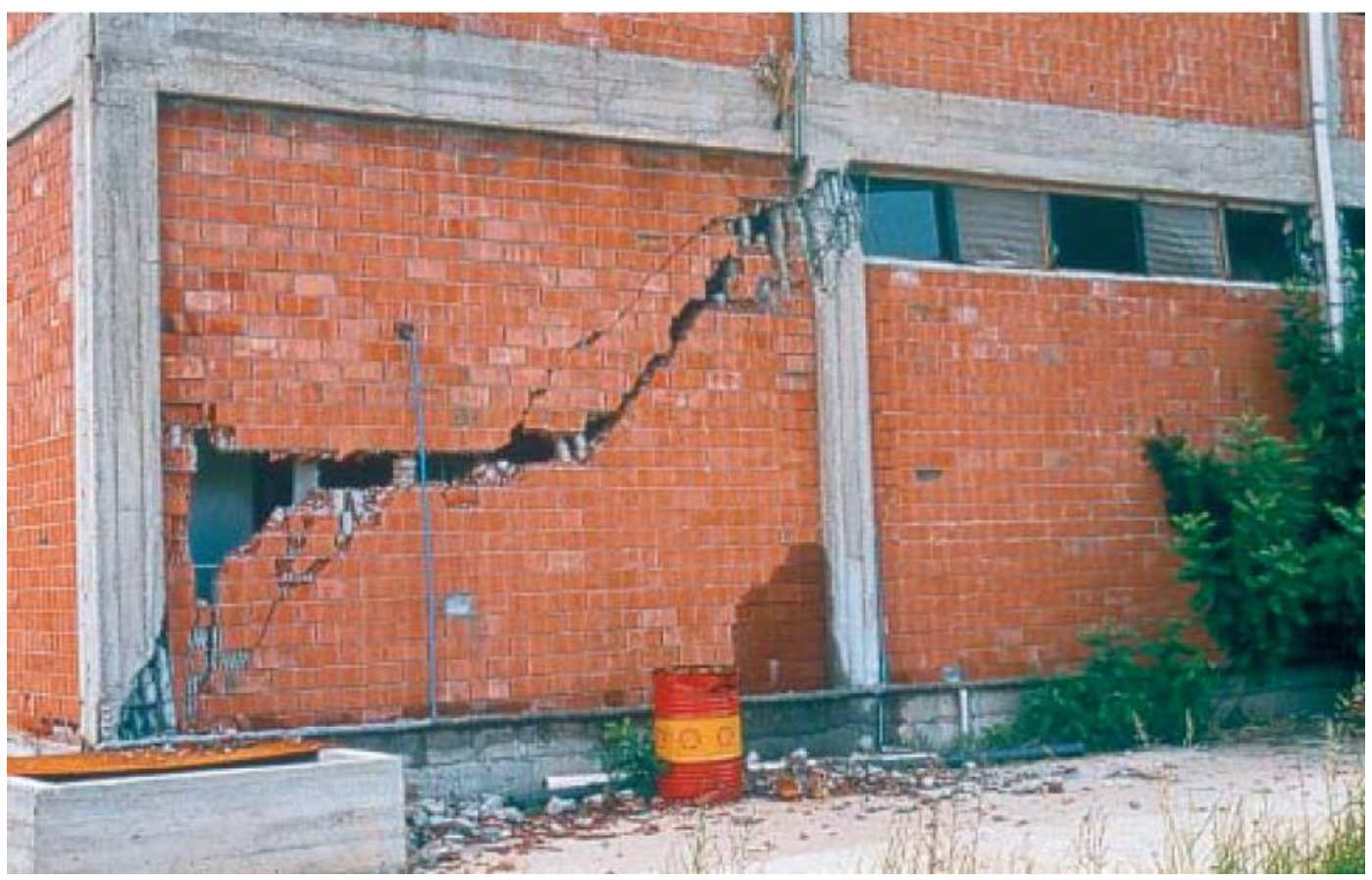

Fig. 7. Damage on ground story due to short column effect.

In all of the reinforced concrete structures, dead load $\mathrm{p}=2,0 \mathrm{kN} / \mathrm{m} 3$, live load $\mathrm{q}=1,50 \mathrm{kN} / \mathrm{m} 3$, the modulus of elasticity (Young's module) $\mathrm{E}=28 \mathrm{GPa}$, Poisson's ratio $v=0.20$ and the unit weight $\rho=24 \mathrm{kN} / \mathrm{m}^{3}$ are assumed. The sections of structural elements are rectangular and their dimensions are kept constant, columns are $50 \mathrm{~cm} \times 50 \mathrm{~cm}$ and beams are $25 \mathrm{~cm} \times 50 \mathrm{~cm}$, for all stories. The substructure and the superstructure are modelled with surface element. The soil mediums are assumed to be isotropic and homogeneous. The damping of the soil-structure models is assumed to be $8 \%$.

\section{Results and Discussions}

In this study, dynamic analyses of Model A, Model $\mathrm{B}$ and Model $\mathrm{C}$ types buildings, which built in Adapazari downtown and Maltepe soil conditions were carried out. The outcomes of these analyses were plotted as the distribution of the displacement time histories for top story respect to base level (Figs. 8,10,12) and for ground story respect to base level (Figs. 9,11,13). The proportion between two responses of buildings built in Adapazari downtown and Maltepe soil conditions were illustrated to monitor the contribution of soil effect on the failure of RC moment resisting frame buildings (Figs. 1416).

Regarding Model A1 and A2 type buildings, the displacements in the ground story, which is formed weak story, increase and become double, when the displacements of the top story turn to be almost close to one another. Because of the heavy masonry infill walls enlarge in the upper stories, the displacements of both the top story and the ground stories in Model A3 type buildings excessively increase and the building are pressurized very much. In addition, the slight stability, which is observed in Model A1 and A2 type buildings, deteriorate.

The soft story problem is simulated in the Model B type buildings. Both of displacements in the top stories of Model B1 and B2 type buildings almost same, such as Model A type buildings. But, a careful study of the results in Fig. 11, leads to observations of remarkable increasing in the ground stories, which is formed soft story. Because of the heavy masonry infill walls enlarge in the upper stories and the lateral stiffness and strength suddenly changes, the displacements in ground stories of Model B2 type buildings two times bigger than the Model B1 type buildings. If the heavy masonry infill walls augment, either the displacements in the top stories or ground stories significantly increases.

In Fig.s 12-13, it can be observed that when the heights of ground storey rise, the displacements of ground storey, which is formed short column effect, increase. When the number of upper stories is reproduced, it is observed the remarkable increasing the displacements of Model A3 type buildings. 


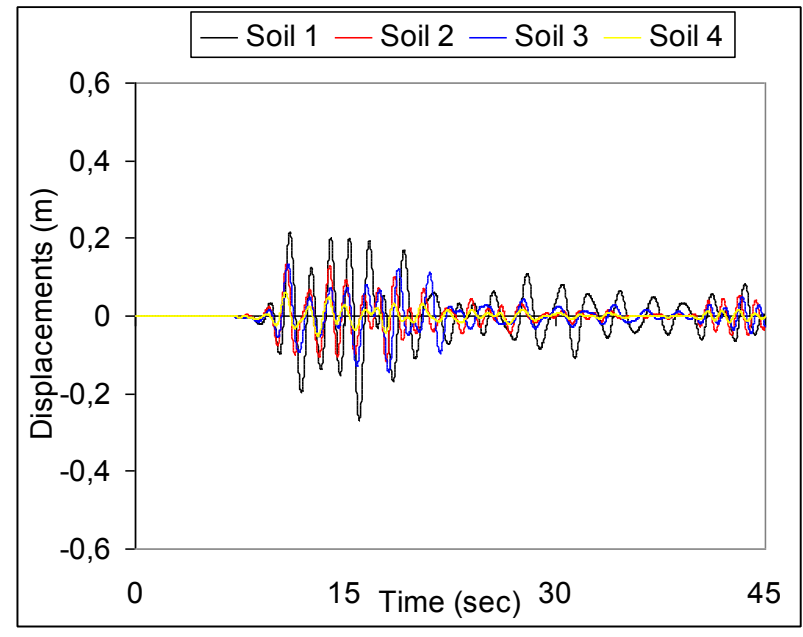

A1
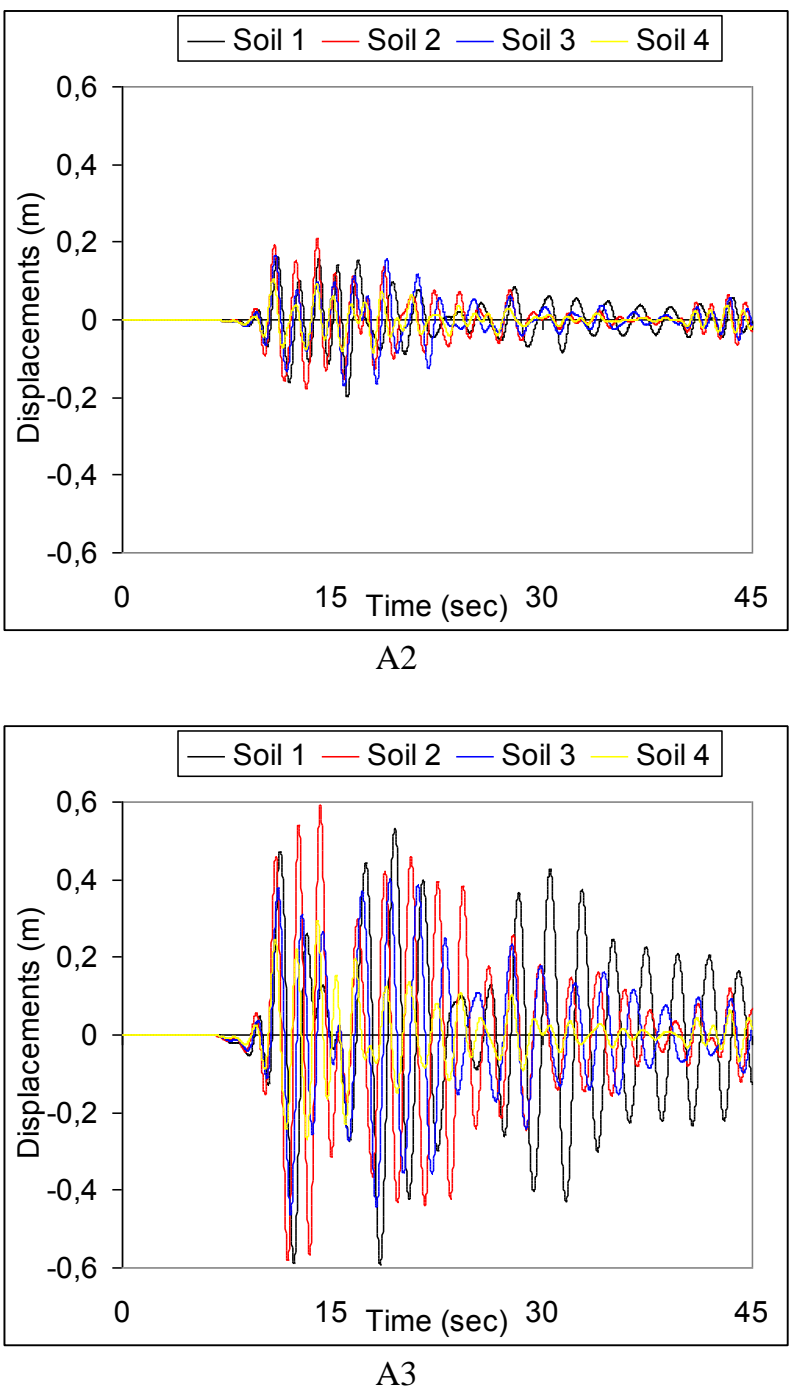

Fig. 8. Displacement time histories for top story respect to base level for four soil types

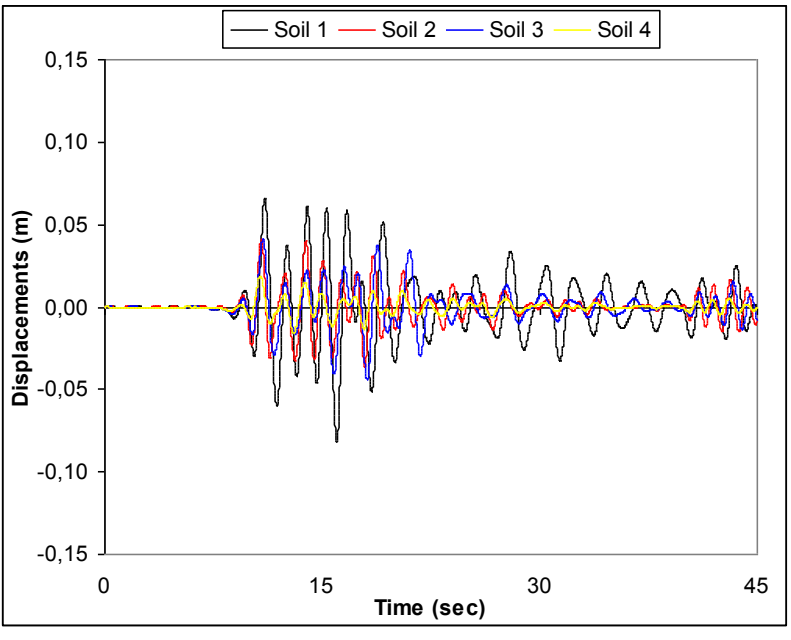

A1

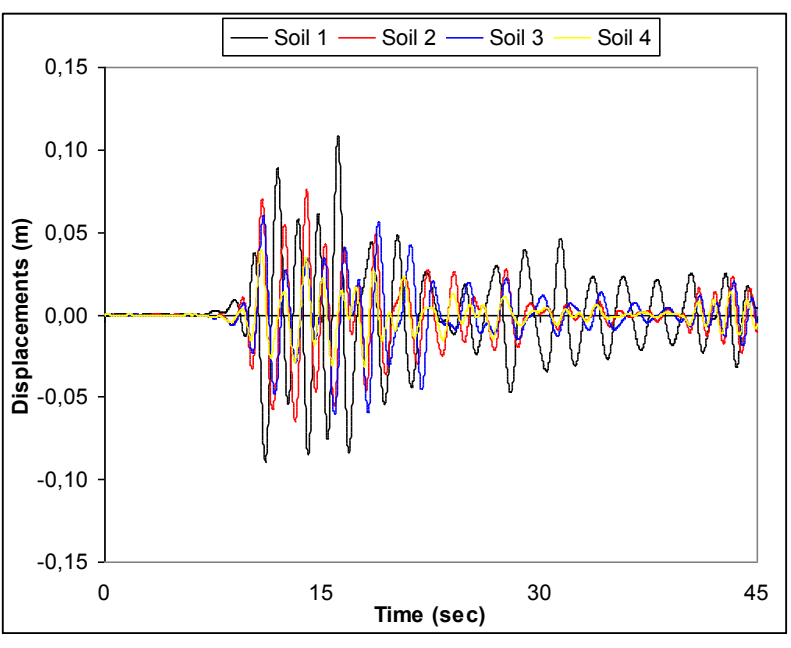

A2

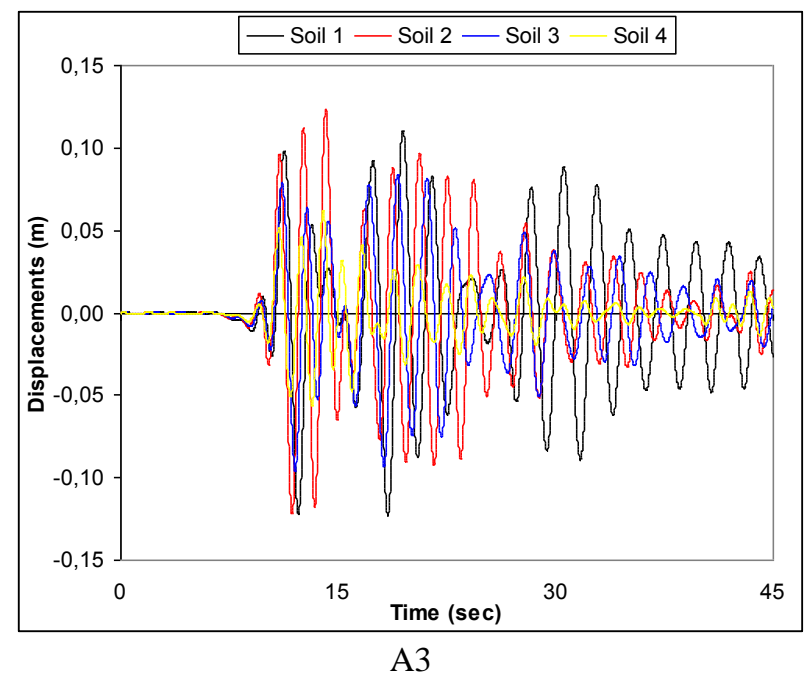

Fig. 9. Displacement time histories for ground story respect to base level for four soil types 


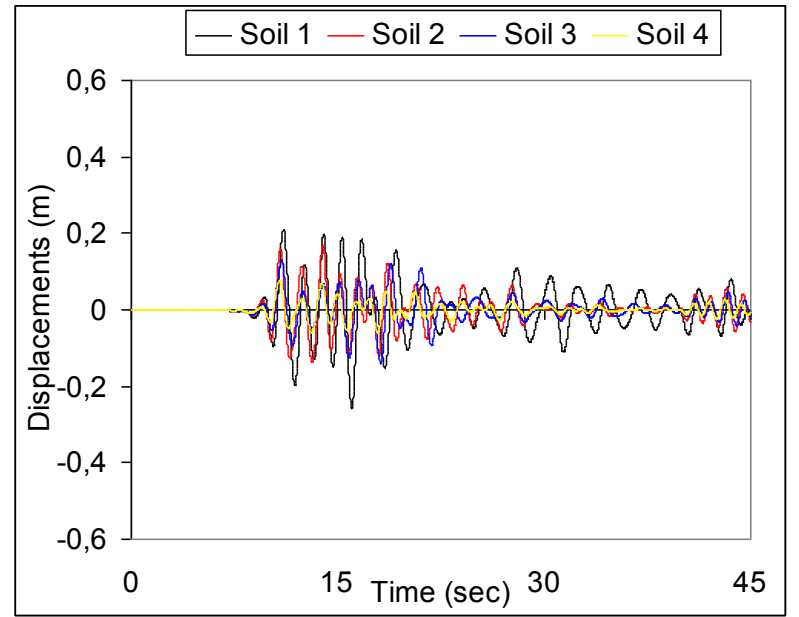

Model B1

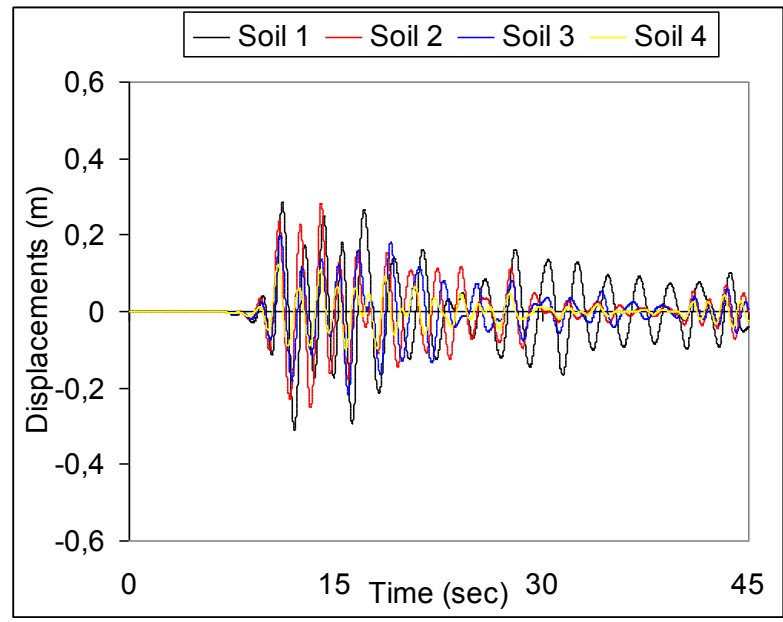

Model B2

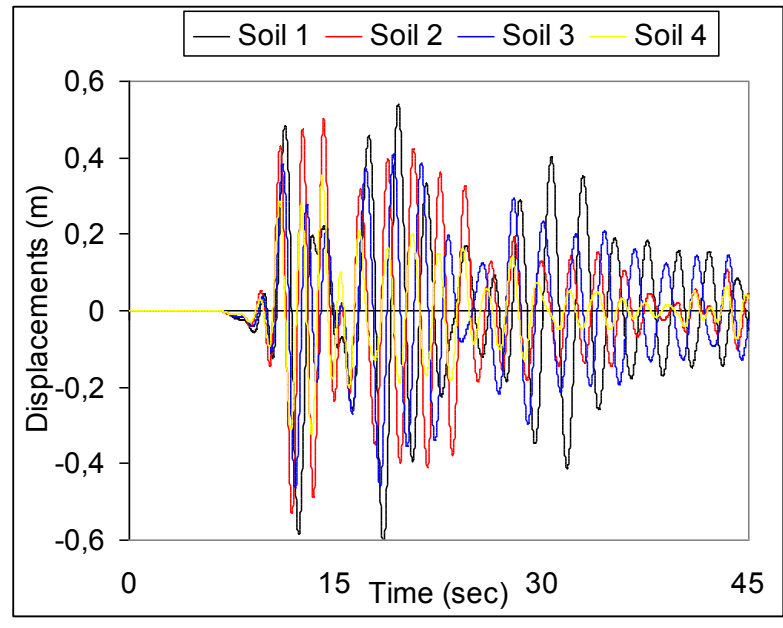

Model B3

Fig. 10. Displacement time histories for top story respect to base level for four soil types

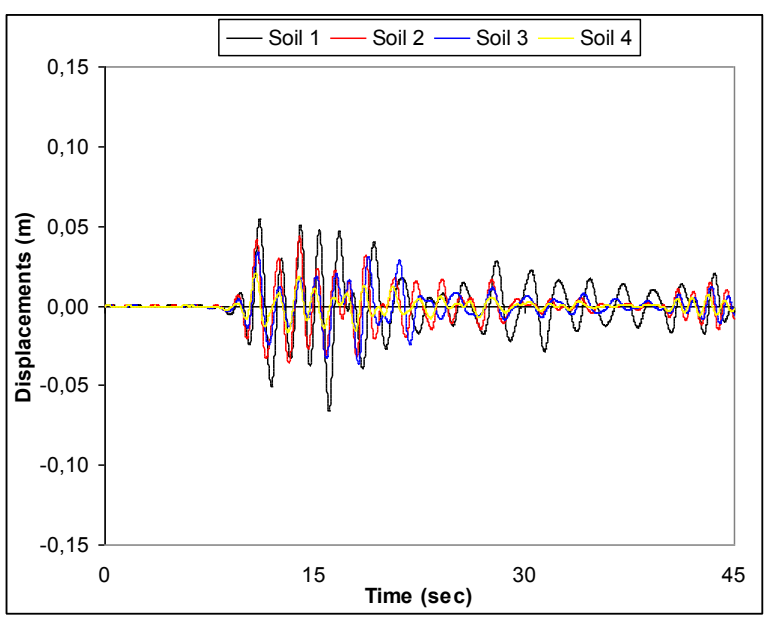

Model B1

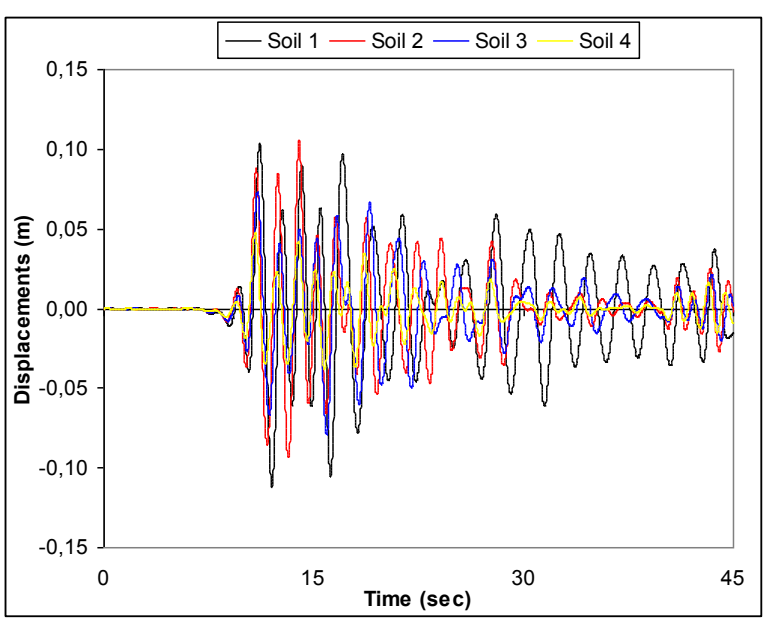

Model B2

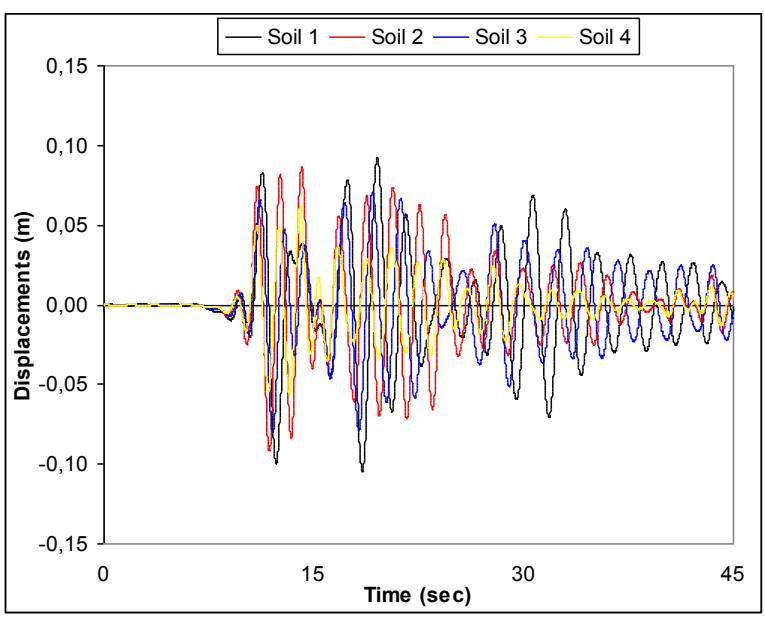

Model B3

Fig. 11. Displacement time histories for ground story respect to base level for four soil types 


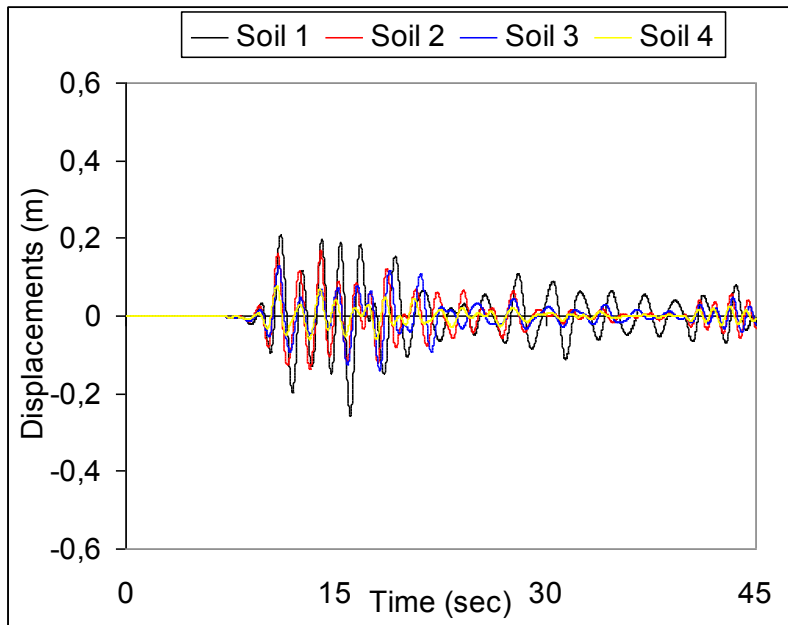

Model C1

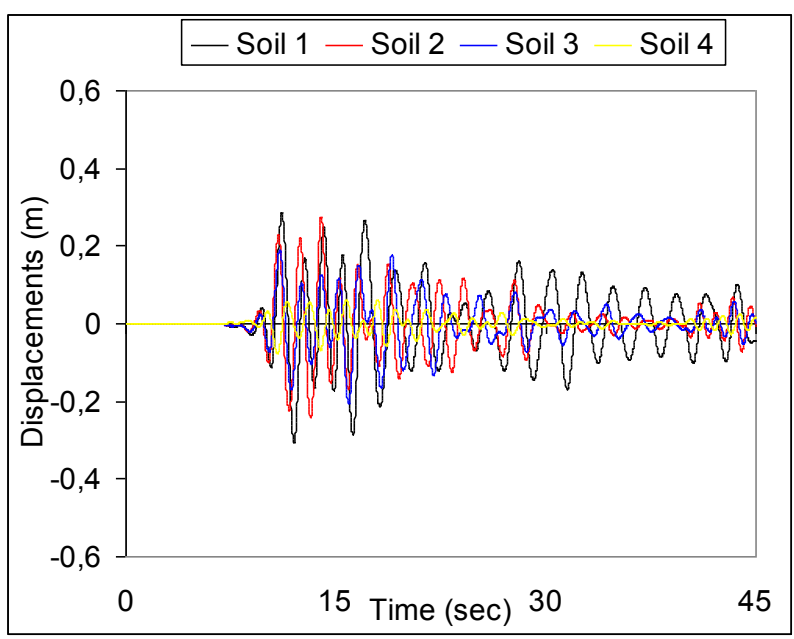

Model C2

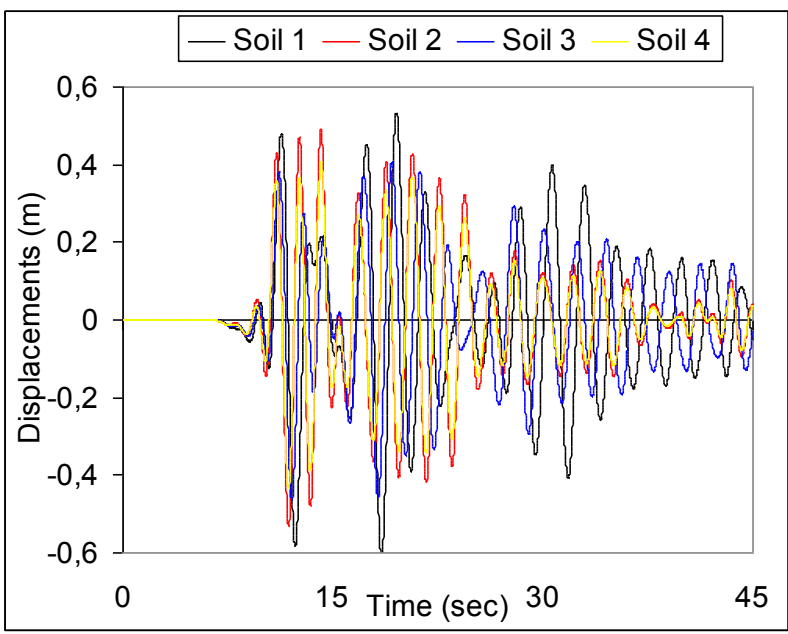

Model C3

Fig. 12. Displacement time histories for top story respect to base level for four soil types

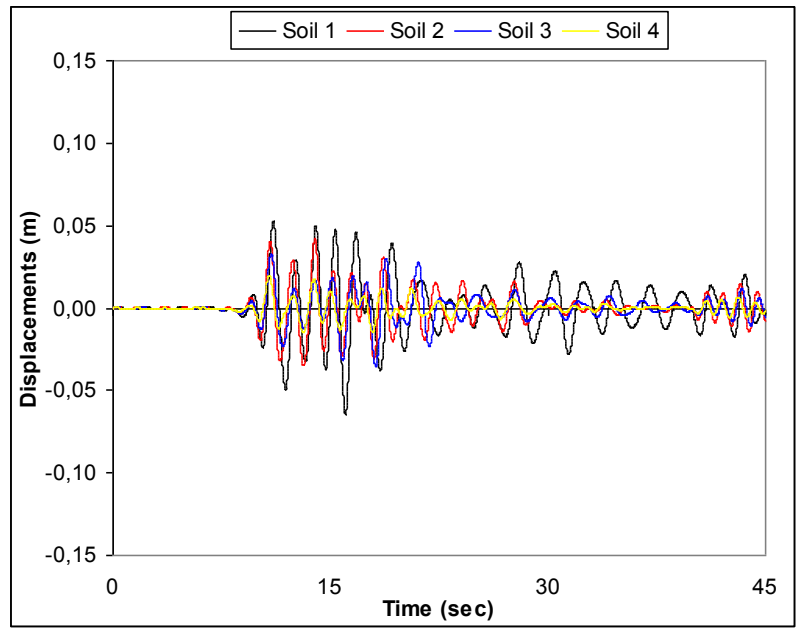

Model C1

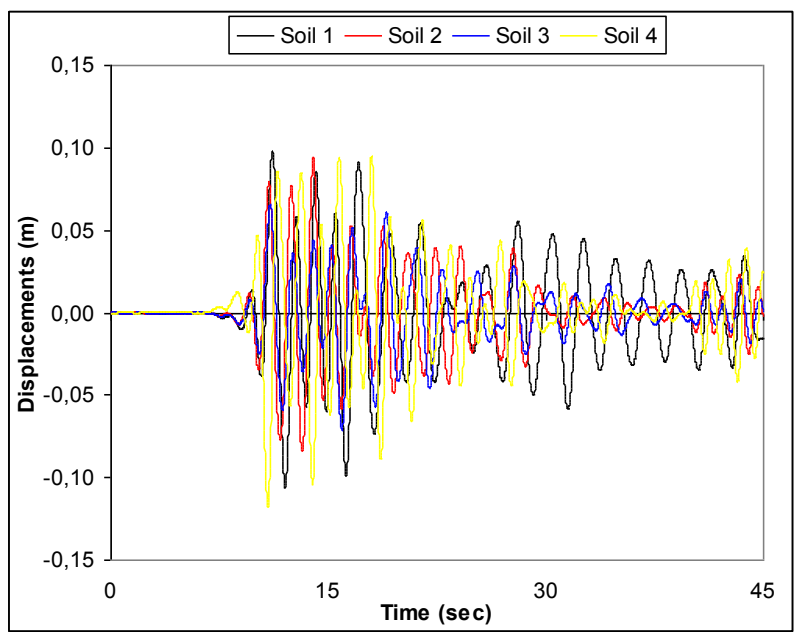

Model C2

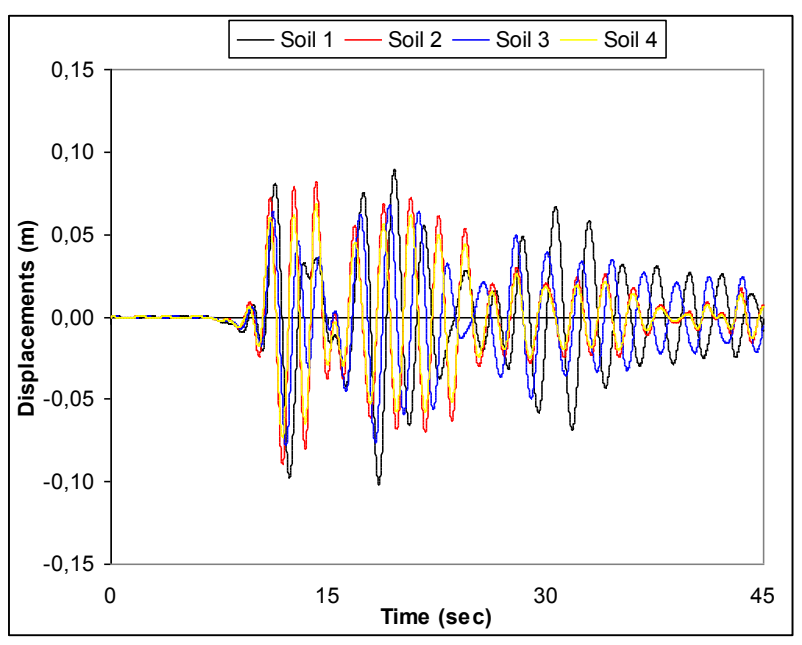

Model C3

Fig. 13. Displacement time histories for ground story respect to base level for four soil types 


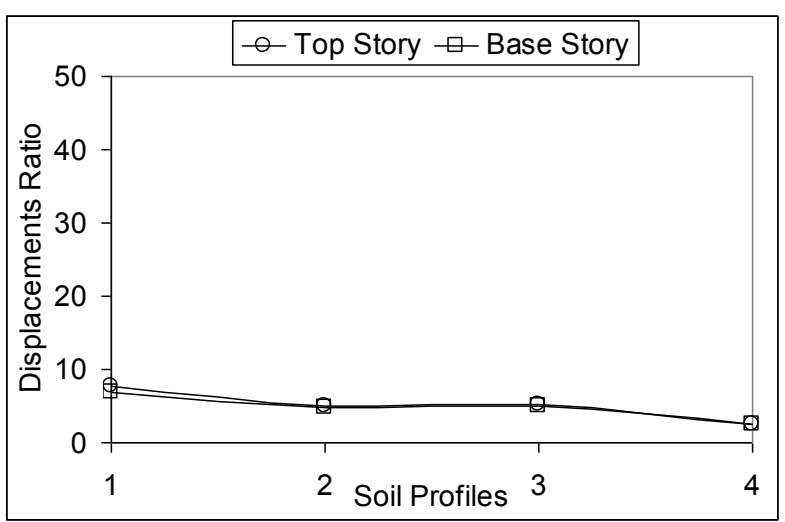

Model A1

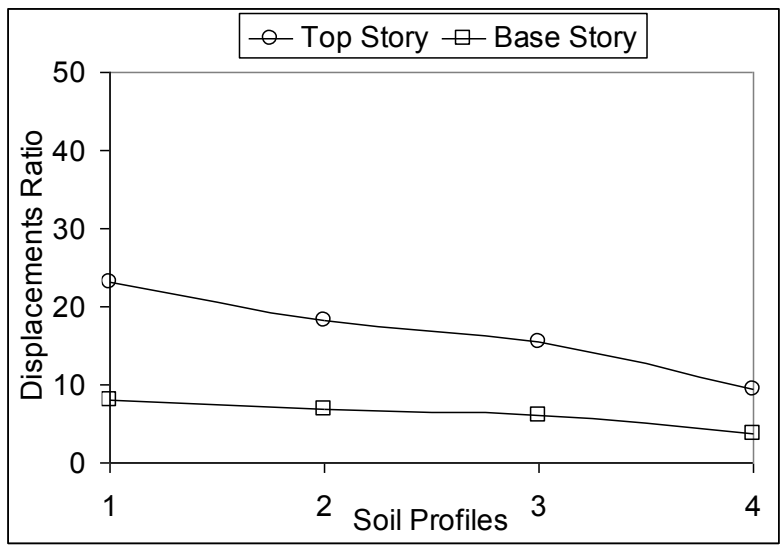

Model A2

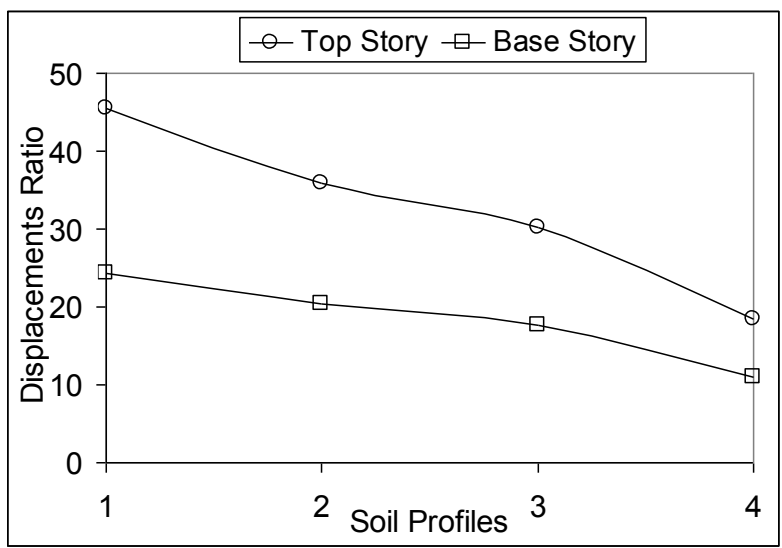

Model A3

Fig. 14. Displacements ratio respect to Maltepe soil for four soil types

When the Model C1 are compared with Model C3 type buildings, the displacements of buildings, especially in the ground stories, in the Adapazari
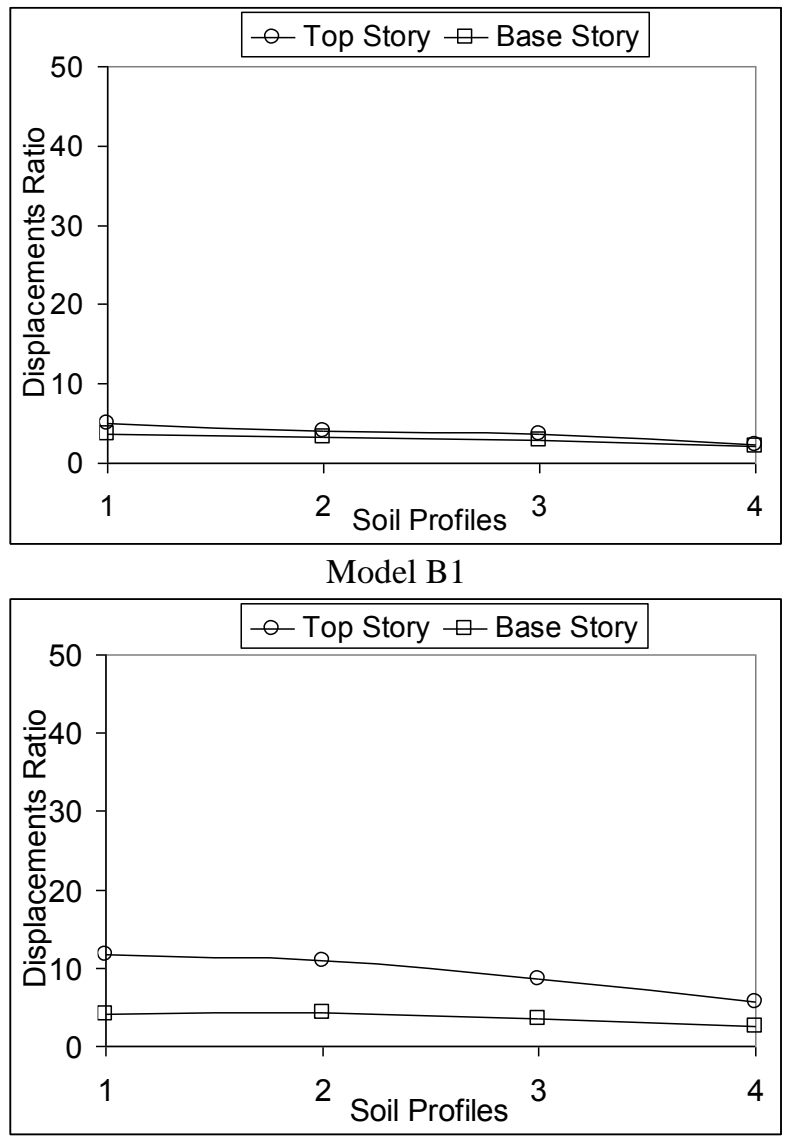

Model B2

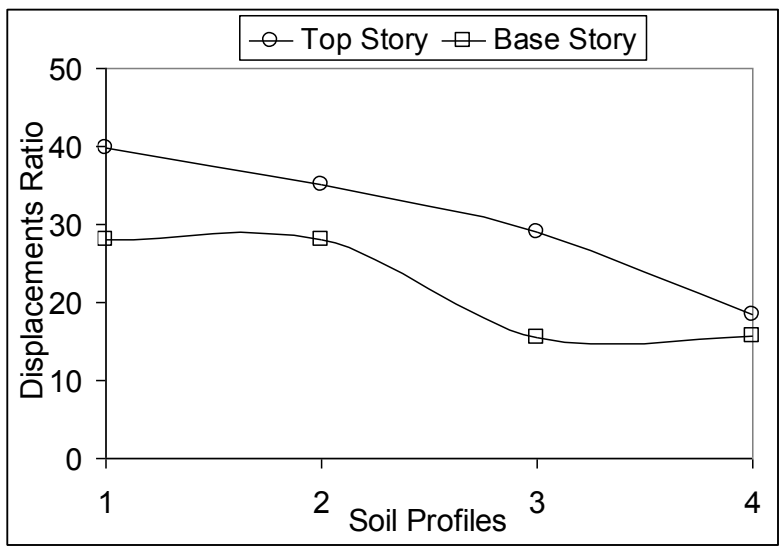

Model B3

Fig. 15. Displacements ratio respect to Maltepe soil for four soil types

downtown soils sharply intensify respect to Maltepe soil conditions with the increment of the ground storey and the number of upper stories. 


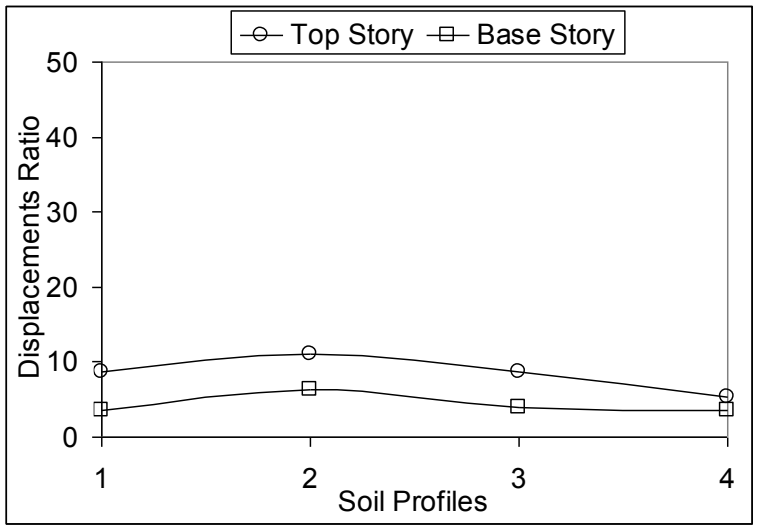

Model C1

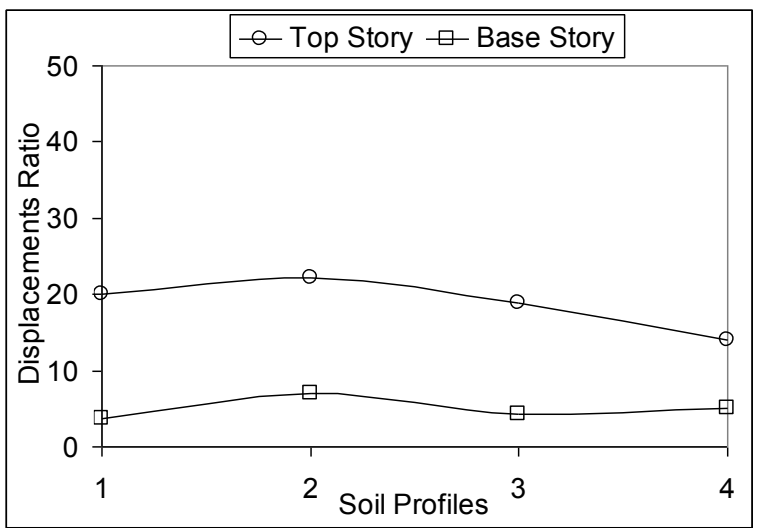

Model C2

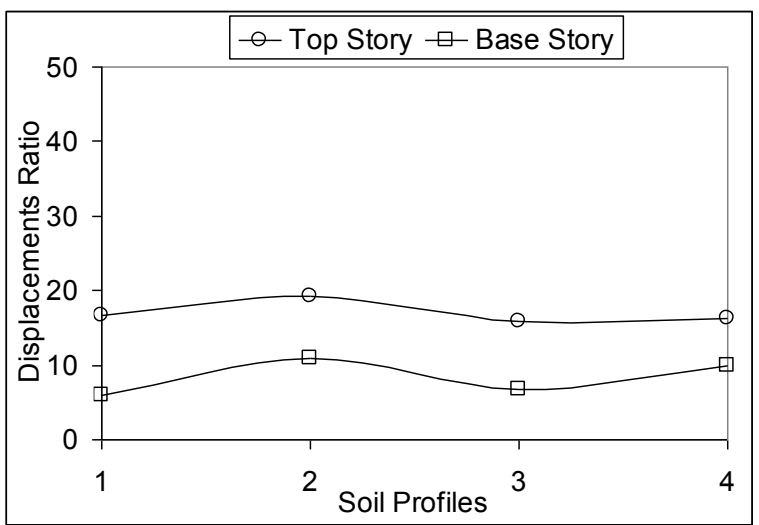

Model C3

Fig. 16. Displacements ratio respect to Maltepe soil for four soil types

It can be observed from the Fig.s 13-14, when the irregularities are multiplied, the response of buildings in the soft soils, Adapazari downtown soil conditions, is became worse respect to stiff soil, Maltepe soil conditions. Comparing to the Model A type buildings, the displacements in the top stories and the ground stories are very close to each other in Model B type buildings. That is because the higher stories behave like a rigit block. On the other hand, the displacements in ground stories of Model B1 and B2 type buildings are rather closer.
However, those values immediately rise very high since the intensiveness of rigid block behaviours in the upper stories of Model B3 type buildings.

\section{Conclusion}

The present study attempts to investigate the contributing factor of soil conditions in the failure of RC moment resisting frame buildings built in Adapazari downtown. The numerical results examined in this study are focused on the response 
amplitudes in the displacements of top storey and ground storey, which were is formed the some irregularities such as soft story, weak story and short column effect.

It can be observed from the results, when the heavy masonry infill walls enlarge in the upper stories, the response of buildings in the soft soils, Adapazari downtown soil conditions, is became worse respect to stiff soil, Maltepe soil conditions. Because of the heavy masonry infill walls enlarge in the upper stories in the all of types of soil-structure models, the displacements in the ground story, which is formed weak and soft stories, excessively increase. Since the higher stories behave like a rigit block, the response of buildings were deteriorated and the building are pressurized very much. As it was well known, the weak storey, soft storey and the short column effect are the main reason caused to damage and collapse of the building during the earthquakes. Furthermore, when the buildings were, which had these irregularities, built on soft soil such as Adapazari soil conditions, the displacements of ground and top stories terribly amplify and the buildings pressurize over the elastic limit. Therefore, if the buildings in the soft soil had the some irregularities, it is not possible to keep away from the excessive damage and collapse.

The soft soil plays a significant role as contributing factor and causes to deteriorate the response of buildings, which had some irregularities. Consequantly, it should be avoided from all of irrgularities types in the buildings, which is built in the soft soil such as Adapazari soil conditions.

\section{References}

[1] M.H. Arslan MH, Korkmaz H, 2007. What is to be learned from damage and failure of reinforced concrete structures during recent earthquakes in Turkey? Eng. Fail. Anal. 14: 1-22.

[2] Sancio RB, Braya JD, Stewartb JP, Youdc TL, Durgunoglu HT, Onalp A, Seeda RB, Christensenc C, Baturayb MB, Karadayilar T, 2002. Correlation between ground failure and soil conditions in Adapazari, Turkey. Soil Dyn. and Earth. Eng., 22: 1093-1102.

[3] USGS, 2000. Implications for Earthquake Risk Reduction in the United States from the
Kocaeli, Turkey, Earthquake of August 17, 1999. U.S. Department of the Interior: Babbitt, Bruce and the U.S. Geological Survey: Groat, Charles G. Denver, United States of America.

[4] Gullu H. and Pala M., 2014. On the resonance effect by dynamic soil--structure interaction: A revelation study. Natural Hazards, 72 (2), 827-847.

[5] Aydemir ME, 2013. Inelastic displacement ratios for evaluation of stiffness degrading structures with soil structure interaction built on soft soil sites. Struct Engng and Mech, An Int'1 J, 45 (6), 741-758.

[6] Pala, M; Caglar, N; Elmas, M; Cevik, A; Saribiyik, M. 2006. Dynamic soil-structure interaction analysis of buildings by neural networks. Construction and Building Materials, 22, 330-342.

[7] Ben Jamaa S, Shiojiri H, 2000. A method for three dimensional interaction analysis of pilesoil system in time domain. Transactions of the Japan Society for Computational Engng and Science.

[8] Jaya KP, Meher Prasad A, 2002. Embedded foundation in layered soil under dynamic excitations. Soil Dyn Earthquake Engng. 22. 485-498.

[9] Lysmer J, Kuhlemeyer RL, 1969. Finite element model for infinite media. J Engng Mech Div, ASCE. 95, 859-877.

[10] Wolf JP, Song C, 1996. Finite-element modelling of unbounded media. England: Wiley.

[11] White W, Valliappan S, Lee IK, 1977. Unified boundary for finite dynamic models. J Eng Mech ASCE. 103 (5), 949-964.

[12] Takewaki I, 1998. Remarkable response amplification of building frames due to resonance with the surface ground. Soil Dyn Earthquake Engng, 17, 211-218.

[13] Dogangun A, 2004. Performance of reinforced concrete buildings during the May 1, 2003 Bingo 1 Earthquake in Turkey. Eng. Struct, 26, 841-856.

[14] Sezen H, Whittaker AS, Elwood KJ, Mosalam KW, 2003. Performance of reinforced concrete buildings during the August 17, 1999 Kocaeli, Turkey earthquake, and the seismic design and construction practice in Turkey. Eng Struct, 25, 103-114. 